\title{
THE ENGAGEMENT OF SECONDARY SCHOOL LEARNERS FOR LEARNING SCIENCE BY RESPONSIBLE RESEARCH AND INNOVATION
}

\author{
Palmira Peciuliauskiene \\ Lithuanian University of Educational Sciences, Vilnius, Lithuania
}

\begin{abstract}
The article deals with the role of responsible research and innovation (RRI) in promoting intrinsic motivation of secondary school learners. RRI is a new concept highlighted by the European Commission that refers to the process which requires a dialogue between scientists and all citizens including the young generation to align the results of research with societal needs in a better way. RRI deals with uncertain areas of knowledge, where arguments and values matter as much as facts. It gives students an opportunity for responsibility and selfexpression for coming to informed decisions about the science innovation and their impact. This situation requires a deeper look into the problem of motivation for learning science from the aspect of RRI activity. The research problem is formulated as a question: how does responsible research and innovation in science education promote intrinsic motivation of secondary school learners. Learners' intrinsic motivation was analysed on the basis of SelfDetermination Theory (STD). According to STD, it is important to fulfil three basic psychological needs of learners: the need for autonomy, the need for competence and the need for relatedness. Intrinsic motivation inventory (IMI) was used to assess the participants' intrinsic motivation related to the RRI activity in science. The article describes the results of RRI project ENGAGE in Lithuania.
\end{abstract}

Keywords: responsible research and innovation; intrinsic motivation; inquiry-based learning.

\section{Introduction}

The 21st century is famous for the fast advancement in Science and Technologies but fewer young people seem to be interested in science. Why this? The answer was given by Healey (2005): "Most staff, when asked about how their research impacts on teaching, point to the way in which their research findings are integrated into their lecture courses. There are many more ways of linking research and teaching than students learning about subject knowledge through lectures" (Healey, 2005, 68). Griffiths (2004) identified four ways of the implementation of research into education: Research-led (Curriculum is structured around teaching subject content); Research-oriented (Curriculum emphasises teaching processes of knowledge construction in the subject); Research-tutored (Curriculum emphasises learning focused on students writing 
and discussing papers or essay); Research-based (Curriculum emphasises students undertaking inquiry-based learning) (Griffiths, 2004).

Students are engaged in science when they are involved in research, for example, through various forms of active learning, such as inquiry-based learning (Healey \& Roberts, 2004; Healey, 2005). The problem of the attractiveness of the science subject at school is related to different aspects of inquiry based science learning (IBSL): diagnosing situations, formulating problems, critiquing experiments and distinguishing alternatives, planning investigations, researching conjectures, searching for information, constructing models, debating with peers using evidence and representations, and forming coherent arguments (Minner et al., 2010).

While learners engage in inquiry as a means, they are supposed to also learn scientific content knowledge through inquiry (Arnold, Kremer, \& Mayer, 2014). The acquisition of core practices, such as modeling and argumentation, are deemed essential for responsible citizenship and success in the 21 st century (Beernaert et al., 2015; Pellegrino \& Hilton, 2013).

Various European projects have been helping teachers foster students' inquiry based science learning (IBSL) abilities for them to be able to discuss socio-scientific issues (Okada, Young, \& Sanders, 2015). The European Commission has highlighted the importance of Responsible Research and Innovation (RRI) in Science Education through its Science in Society programmes (FP7 \& Horizon 2020). ENGAGE project has highlighted the importance of students developing evidence-based opinion related to science in their lives (Sherborne et al., 2014). The European project ENGAGE (engagingscience.eu) aim is to increase awareness of Responsible Research and Innovation (RRI) through Inquiry Based Learning (IBL) by reaching 12.000 teachers and 360.000 students in 14 countries (Okada et al., 2015). The ENGAGE project also aims at spreading the teaching and learning of RRI at scale, by connecting cutting-edge Science and Technology with inquiry based learning.

RRI deals with uncertain areas of knowledge, where arguments and values matter as much as facts. According to Rocard (2007), historically two pedagogical approaches in science teaching can be: deductive (top-down transmission) and inductive (bottom-up) approaches. In deductive approaches, teachers' role was confined to presenting the scientific facts and to giving examples of applications. In the inductive approaches teachers' role was is to give space for student's argumentation, observation, experimentation and evaluation. RRI corresponds to the inductive approaches, were arguments and values are important.

Another aim of the ENGAGE project is to engage school students in critical discussions on current scientific topics through Socio-Scientific Issues (SSI). SSI are socially controversial (or socially alive) topics or issues which have a 
scientific component but also incorporate other disciplines and interests (political, economic, ethical, etc.) and which involve the evaluation of moral and ethical aspects (Evagorou, Jimenez-Aleixandre, \& Osborne, 2012). The latest discoveries related to nanotechnology, biotechnology and artificial intelligence are closely connected to citizens' lives. The impact of scientific innovations is unpredictable. This requires learners to be able to deal with uncertainties, as well as to better understand the potential benefits and risks of science discovery (Von Schomberg, 2013). SSI can serve as a good teaching and learning context, allowing students to understand the importance of science in everyday life, encourage the participation in discussion and debate, provide a framework for understanding scientific content and the nature of science, and help the development of critical thinking and argumentation (Evagorou et al., 2012; Zeidler \& Nichols, 2009).

In the related literature, there has been an emphasis in the study of SSI regarding students' decision making and conceptual understanding (Espeja \& Lagarón, 2014). This situation necessitates for a deeper look into the problem of SSI at secondary school - by the aspect of intrinsic motivation for learning science of secondary school learners. There is a greater need for research to identify those aspects of science teaching that make school science engaging for pupils.

According to Self-Determination Theory (SDT), intrinsically motivated individuals engage in certain activities freely, led by the feelings of interest and enjoyment (Ryan \& Deci, 2002). The main idea of SDT is that humans are active and growth-oriented, seeking for the actualisation of their potentialities and fulfilling their basic psychological needs: autonomy, competency and social relatedness. Intrinsic motivation arises from a desire to learn a topic due to its inherent interests, self-fulfillment, enjoyment and achievement of mastery of the subject (Ryan \& Deci, 2009).

The discussed situation highlights the scientific problem, which is formulated as a question: how does responsible research and innovation in science education promote intrinsic motivation of the secondary school learners?

The object of the research is intrinsic motivation of secondary school learners for learning science.

The aim of the research is to reveal the impact of responsible research and innovation on intrinsic motivation of secondary school learners for learning science.

The objectives of the research are as follows:

1. How does RRI activity engage school students in science?

2. How are the engagement variables related to autonomy, competency and social relatedness of RRI activity? 


\section{Methodology}

The research methodology. The research methodology is based on constructivist theory of education, which acknowledges IBSL as an efficient educational technology with emphasis on experiences, questioning, planning and recording with a purpose to obtain evidence; supporting knowledge claims with observations, authentic and problem-based learning activities; with emphasis on collaborative group work and interaction, construction of argumentation through communication, as well as the development of autonomy and self-regulation (Igwebuike \& Oriaifo, 2012). Inquiry is the process of formulating problems, critiquing experiments, planning investigations, searching for information, constructing models, debating with peers using evidence and representations, and forming coherent arguments (Linn, Davis, \& Bell, 2004).

Method of research. The data presented in the current research is part of the ENGAGE project in Lithuania. The content about RRI was used from ENGAGE project: slide presentation with activities for students, guidelines for teachers with pedagogical suggestions, and web links with science-in-the-news or video clips with scientists. Research-based (Griffiths, 2004) way was undertaken for implication of RRI in science education. Research-based education was realised by two problem solution science lessons. For example, in the first lesson Animal testing, students apply their knowledge of the gas exchange system to explain what causes asthma. They look at scientific evidence to decide how essential animal testing is employed in the development of new asthma drugs. In the second lesson, they are introduced to three types of ethical thinking and they apply these principles and practice the skill of ethical thinking by looking at ethical arguments for and against the ban on animal testing, which they use in a class debate (conversation). According to Ocada (2015), by the end of these two cycles, the students are equipped with both scientific concepts and principles that they need to respond to the original problem.

A five-step method following the 5E model (Engage, Explore, Explain, Elaborate, Evaluate) was carried out in coordination of formal (Engage, Explore, Evaluate) and informal (Explain, Elaborate) learning. First (Engage), teachers selected questions designed to activate or provide students with the essential background knowledge. Controversial SSI were introduced to students at the beginning of a lesson. It provided a productive learning context to engage students and extend their understanding for developing evidence based opinion. At the second step (Explore), the students organised concepts and facts into evidence. The third and fourth step (Explain, Elaborate) were implemented in informal activity. At this stage, the students elaborated opinion and justification using argumentation (claim, evidence and reasoning). Partnerships among schools, science centers, science-media and science-based business were useful for 
students in elaborating their opinion and justification of collaborative research (co-inquiry) techniques and using science in real settings (Okada, 2013). The last step of 5E model (Evaluation) was implemented in the classroom at the second problem solution science lesson. As the last step, the teacher organised a debate which explained problem-based solutions.

The instrument of quantitative research. Intrinsic Motivation Inventory (IMI) was used to assess the participants' subjective experience related to target activity in laboratory experiments (Ryan, 1982). There are seven subscales in this instrument: the subscale of participants' interest/enjoyment, perceived competency, effort, value/usefulness, felt pressure and tension, perceived choice (or autonomy of activity) and relatedness. The results of each subscale in our research are represented by the interval scale, which ranges from 1 to 100 points.

The sample and sampling of quantitative research. We organized on-line courses of six weeks (19 October - 30 November 2015) for science teachers in order to appraise how contemporary science can engage students and get them to thinking and talking, to master the use of a 5E lesson to develop RRI/inquiry skills, and to be able to design their own problem-based lessons for RRI/enquiry skills.

47 science teachers completed the on-line courses. They experienced the obtained theoretical materials in the classrooms with their eighth-tenth form students.

The research sample only of eighth form students was representative (probability cluster sample). The research clusters were the largest cities of Lithuania. The classes were selected on the basis of probability cluster sample and all learners of the selected class were tested.

The research sample was reliable as it involved 400 school students. The total population was 25000 eighth form school students (EMIS - Education Management Information System). The confidence interval being $5 \%$, the confidence level is $95 \%$. Hence, the research sample should have included 379 respondents. Therefore, the probability (confidence level) is $95 \%$, so the obtained data can shift only by $5 \%$ from the population parameters (confidence interval).

\section{Results}

Exploratory factor analysis (EFA) was used for investigating the variables of motivation. EFA complies with the research aim because it reduces the data to a smaller set of summary variables and to exploring the underlining theoretical structure of the phenomena.

The first subscale of IMI is called Interest/enjoyment. This subscale enables the self-reporting measure of intrinsic motivation. The seven observed variables (1. I enjoyed doing this activity very much; 2. This activity was fun to do. 3. 
I thought this was a boring activity; 4. This activity did not hold my attention at all; 5. I would describe this activity as very interesting; 6. I thought this activity was quite enjoyable; 7. While I was doing this activity, I was thinking about how much I enjoyed it) of the first subscale Interest/enjoyment of IMI can be reduced to a lower number of unobserved variables called factors.

EFA was carried out according to Rietveld and Van Hout (1993, p. 291) factor analysis diagram. That offers an overview of the steps in factor analysis: reliable measurements, correlation matrix, factor analysis versus principal component analysis, the number of factors to be retained, factor rotation, as well as the use and interpretation of the results. The application of factor analysis was taken into account, since variables can be measured at a range level, normally distributed (Field, 2000, p. 444). The skewness and kurtosis of the variable from the subscale Interest/enjoyment were appropriate within the tolerable range for assuming a normal distribution. The values for asymmetry and kurtosis between -2 and +2 are considered acceptable in order to prove normal univariate distribution (Gravetter \& Wallnau, 2014). An approximately normal distribution was evident for the composite score data in the current study, thus the data were well suited for parametric statistical analyses because the values of skewness and kurtosis ranged between -2 and +2 .

The Kaiser-Meyer-Olkin test (KMO-test) was used for sampling adequacy. The sample is adequate if the value of KMO is greater than recommended value 0,6 . It was determined that $\mathrm{KMO}=0,753$ for the observed variables of the subscale Interest/enjoyment in IMI. The inter-correlation checked by using Bartlett's test of sphericity was significant $\left(\chi^{2}(28)=828,576, p<0.05\right)$. The hypothesis regarding uncorrelated variables was rejected, so factor analysis could be used.

We realised that all the variables according to Measure of Sampling Adequacy (MSA) were suitable for factor analysis: I enjoyed doing this activity very much $\left(0,790^{\mathrm{a}}\right)$; This activity was fun to do $\left(0,788^{\mathrm{a}}\right)$; I thought this was a boring activity $\left(0,719^{\mathrm{a}}\right)$; This activity did not hold my attention at all $\left(0,579^{\mathrm{a}}\right)$; I would describe this activity as very interesting $\left(0,858^{\mathrm{a}}\right)$; I thought this activity was quite enjoyable $\left(0,866^{\mathrm{a}}\right)$; While I was doing this activity, I was thinking about how much I enjoyed it $\left(0,836^{\mathrm{a}}\right)$ (a - Measures of Sampling Adequacy - MSA).

It was decided to use principal component analysis (PCA) for investigating the variable of communication on IMI subscale Interest/enjoyment. The aim of the factor analysis was to explain dispersion using the smallest number of factors. The number of factors was determined by the Guttman-Kaiser rule. Two factors (Table 1) corresponded to Guttman-Kaiser rule because of their eigenvalues (larger than 1). Initial eigenvalues indicated that the first two factors explained 
$50,86 \%$ and $18,41 \%$ of the variance respectively (Table 1 ). The third and all the following factors explained gradually reducing portions of the variance.

The rotation method Varimax was used for the simplification of factor interpretation in PCA. After the initial rotation of factors, the proportion of the first factor decreased to 45,467 \%, while the second increased to 23,812. (Rotation sums of squared loadings, Table 1).

Table 1 Initial eigenvalues of factors and rotation sums of squared loadings of questions group of Interest/enjoyment

\begin{tabular}{|c|c|c|c|c|c|c|c|c|c|}
\hline \multirow[b]{2}{*}{$\begin{array}{l}\text { Com- } \\
\text { ponent }\end{array}$} & \multicolumn{3}{|c|}{ Initial Eigenvalues } & \multicolumn{3}{|c|}{$\begin{array}{l}\text { Extraction Sums of } \\
\text { Squared Loadings }\end{array}$} & \multicolumn{3}{|c|}{$\begin{array}{c}\text { Rotation Sums of Squared } \\
\text { Loadings }\end{array}$} \\
\hline & Total & $\begin{array}{c}\% \text { of } \\
\text { Varian- } \\
\text { ce }\end{array}$ & $\begin{array}{l}\text { Cumula- } \\
\text { tive } \%\end{array}$ & Total & $\begin{array}{c}\% \text { of } \\
\text { Varian- } \\
\text { ce }\end{array}$ & $\begin{array}{l}\text { Cumula- } \\
\text { tive } \%\end{array}$ & Total & $\begin{array}{c}\% \text { of } \\
\text { Varian- } \\
\text { ce }\end{array}$ & $\begin{array}{l}\text { Cumula- } \\
\text { tive } \%\end{array}$ \\
\hline 1 & 3,561 & 50,865 & 50,865 & 3,561 & 50,865 & 50,865 & 3,183 & 45,467 & 45,467 \\
\hline 2 & 1,289 & 18,414 & 69,279 & 1,289 & 18,414 & 69,279 & 1,667 & 23,812 & 69,279 \\
\hline 3 & ,748 & 10,682 & 79,960 & & & & & & \\
\hline 4 & , 490 & 7,005 & 86,965 & & & & & & \\
\hline 5 & ,358 & 5,116 & 92,081 & & & & & & \\
\hline 6 & ,335 & 4,780 & 96,861 & & & & & & \\
\hline 7 & ,220 & 3,139 & 100,000 & & & & & & \\
\hline
\end{tabular}

Extraction Method: Principal Component Analysis.

The factor loadings were represented in the rotated component matrix (Table 2). The five variables: I would describe this activity as very interesting; This activity was fun to do; I thought this activity was quite enjoyable; I enjoyed doing this activity very much and While I was doing this activity, I was thinking about how much I enjoyed it were associated with Factor 1. Based on the variables loading highly on Factor 1, we called it Enjoyment.

Table 2 Rotated component matrix of observed motivation variables

\begin{tabular}{|l|l|l|}
\hline \multirow{2}{*}{ Observed variables } & \multicolumn{2}{|c|}{ Latent variables: factors } \\
\cline { 2 - 3 } & F1 (Enjoyment) & F2 (Humdrum) \\
\hline I would describe this activity as very interesting & 0,847 & \\
\hline This activity was fun to do & 0,832 & \\
\hline I thought this activity was quite enjoyable & 0,809 & \\
\hline I enjoyed doing this activity very much & 0,754 & \\
\hline $\begin{array}{l}\text { While I was doing this activity, I was thinking } \\
\text { about how much I enjoyed it }\end{array}$ & 0,686 & \\
\hline This activity did not hold my attention at all & & 0,903 \\
\hline I thought this was a boring activity & & 0,833 \\
\hline
\end{tabular}

Extraction Method: Principal Component Analysis.

Rotation Method: Varimax with Kaiser Normalisation. 
The variables This activity did not hold my attention at all and I thought this was a boring activity had high factor loadings on Factor 2. They did not refer to engagement, so we named Factor 2 as Humdrum.

The correlation between the data of variables for the factor Engagement was explored (Table 3). According to SDT, humans actively seek for the actualisation of their potentialities fulfilling their basic psychological needs: needs for autonomy, competency and social relatedness. Therefore, it was important to determine how the data of the factor Engagement correlated with the data of the second (feeling of competency), fifth (perceived choice) and seventh (interpersonal interactions) subscales.

The strongest statistically significant correlation was determined between students' engagement variables for learning science and the feeling of competency (perceived competence subscale): this activity was fun to do $\left(\mathrm{r}=0,561^{* *}, \mathrm{p}=0,01\right) ;$ I would describe this activity as very interesting $\left(\mathrm{r}=0,557^{* *}, \mathrm{p}=0,01\right)$; I enjoyed doing this activity very much $\left(\mathrm{r}=0,482^{* * *}\right.$, $\mathrm{p}=0,01)$. Hence, RRI gave learners the feeling of competency and promoted positive motivation for learning science.

Table 3 Spearman correlation coefficients of intrinsic motivation variables Engagement and main STD components: autonomy, competence, relatedness

\begin{tabular}{|l|l|l|l|l|l|l|}
\hline & \multicolumn{1}{|l|}{$\begin{array}{l}\text { I enjoyed It was } \\
\text { fun }\end{array}$} & $\begin{array}{l}\text { It was } \\
\text { interestingchoice }\end{array}$ & $\begin{array}{l}\text { Perceived } \\
\text { Perceived } \\
\text { competence }\end{array}$ & Relatedness \\
\hline $\begin{array}{l}\text { I enjoyed doing this activity } \\
\text { very much }\end{array}$ & 1,000 & $0,745^{* *}$ & $0,546^{* *}$ & $0,143^{* *}$ & $0,482^{* *}$ & 0,049 \\
\hline This activity was fun to do & & 1,000 & $0,587^{* *}$ & 0,091 & $0,561^{* *}$ & 0,069 \\
\hline $\begin{array}{l}\text { I would describe this activity as } \\
\text { very interesting }\end{array}$ & & & 1,000 & $0,111^{*}$ & $0,557^{* *}$ & $0,220^{*}$ \\
\hline $\begin{array}{l}\text { Perceived choice while } \\
\text { performing a given activity }\end{array}$ & & & & 1,000 & 0,010 & $0,214^{* *}$ \\
\hline $\begin{array}{l}\text { Perceived competence } \\
\text { Relatedness }\end{array}$ & & & & & 1,000 & $0,213^{* *}$ \\
\hline $\begin{array}{l}* * \text { Correlation is significant at the } 0.01 \text { level (2-tailed). } \\
* . \text { Correlation is significant at the } 0.05 \text { level (2-tailed). }\end{array}$ & & & & \\
\hline
\end{tabular}

A statistically significant but weak correlation was determined between students' engagement variables (Factor 1) for learning science and the interpersonal interaction (the seventh subscale): I would describe this activity as very interesting $\left(\mathrm{r}=0,220^{*}, \mathrm{p}=0,05\right)$.

Moreover, against our expectation, there was a statistically insignificant correlation determined between students' engagement variables (Factor 1) for learning science and feeling of autonomy (Perceived choice while performing a given activity) at RRI activity. 


\section{Discussion}

Claude Bernard, a famous nineteenth-century scientist, stated that science is a "superb and dazzling hall, but one which may be reached only by passing through a long and ghastly kitchen" (Osborne et al., 2003, p. 1074). It is our contention that RRI is a good tool for successful "passing through a long and ghastly kitchen". According to Owen et al. (2012), a responsible innovation evokes a collective duty of care to firstly rethink what we want from innovation and then how we can make its pathways responsive in the face of uncertainty because the societal perception and impacts of technology are difficult (impossible) to predict. Acknowledging the power of innovation to shape our collective future, RRI challenges us, first and foremost, to ask what kind of future we want innovation to bring into the world (Owen et al., 2012).

We investigated how RRI activity at science classroom engages students in science. We also sought to bring to light how the engagement is related with perceived competence, relatedness and autonomy of students. The essential ingredients of motivation are opportunities to choose, challenge, and control over the pace and nature of learning, and collaboration (Osborne et al., 2003). The feeling of competence at RRI activity is fulfilled by evidence-based learning about new technologies and scientific achievements, the feeling of autonomy - by freedom of choice the way of investigation, while the feeling of relatedness - by collaboration carrying out of mini-projects and dialogues of students with scientists.

The conducted research reveals that the need for competency is significant for the engagement in science of new generation learners at RRI activity (Table 3). Evidence-based learning about new technologies and scientific achievements give preconditions for revealing the competence of students. It complies with the opinion of Jurik, Gröschner, and Seidel (2014) that student learning and motivation could be fostered if students receive deep-reasoning questions (Jurik, Gröschner, \& Seidel, 2014). Deep-reasoning questions in science classrooms can provide a rich forum for the exploration of disparate viewpoints. Students' competences appear depending on how they evaluate information pertinent to socio-scientific problems and ethical issues, as well as how they find a solution to solve a dilemma. By engaging students in the discourse on socio-scientific issues, teachers can challenge students' intrinsic motivation.

There is an international push to improve the effectiveness with which scientists communicate. It is acknowledged that the role of communicating science research to a broad range of audiences is the responsibility of a trained science community (Brownell, Price, \& Steinman, 2013a; Mercer-Mapstone \& Kuchel, 2015). RRI requires a dialogue between scientists and students, as well as scientists and teachers. RRI activity is based on collaboration and teamwork 
approach, which encourages intrinsic motivation and promotes student responsibility for learning and communication abilities. The research revealed a statistically significant relationship between the engagement of students in science and relatedness at RRI activity: I would describe this activity as very interesting $\left(\mathrm{r}=0,220^{*}, \mathrm{p}=0,05\right)$.

The conducted research reveals statistically insignificant relationship between engagement in science and autonomy at RRI activity (Table 3). According to Stefanou et al. (2004), autonomy support can be procedural autonomy (students are allowed to choose and handle their own experimental materials, take an active part in hands-on activities), cognitive autonomy support (students may find multiple solutions to problems, receive considerable support in reevaluating their errors) and organisational support (students may make decisions about the layout of the classroom activities). In classrooms with high cognitive autonomy support where students were asked to make cognitive choices related to strategies of the solution, students showed much more enthusiasm and engagement (Stefanou et al., 2004). In our case high procedural and organizational autonomy support was noted in RRI activity.

\section{Conclusions}

One of the important results of this study is that the school students are engaged in RRI activity implemented by Research-based way. Factor analysis reveals the group of variables related to intrinsic motivation for learning science on the basis of IMI scale. The learners point out that RRI activity is very interesting; quite enjoyable; and fun to do. The factor loading of variables with factor Enjoyment is high: I would describe this activity as very interesting $(0,847)$; This activity was fun to do $(0,832)$; I thought this activity was quite enjoyable $(0,809)$.

Another result gained from this study is that the perceived competency and social relatedness are related to variables of the factor Enjoyment. The two basic psychological needs have a different strength and keenness for enjoyment for learning science. The need for competency is significant for the engagement in science of new generation learners at RRI activity. Students' competences appear depending on how they evaluate information related to socio-scientific problems; as well as how they find the dilemma solving solution. The research reveals weak, yet statistically significant relationship between the engagement of students in science and relatedness (student and teacher; student and scientist) at RRI activity. 


\section{Acknowledgements}

The research leading to these results has received funding from the European Community's Seventh Framework Programme FP7/2007-2013 under grant agreement No [612269].

\section{References}

Arnold, J. C., Kremer, K., \& Mayer, J. (2014). Understanding Students' Experiments - What kind of support do they need in inquiry tasks? International Journal of Science Education, 36 (16), 2719-2749.

Beernaert, Y., Constantinou, P. C., Deca, L., Grangeat, M., Karikorpi, M., Lazoudis, A., Casulleras, R. P., \& Welzel-Breuer, M. (2015). Science Education for Responsible Citizenship. EU 26893, European Commission.

Brownell, S. E., Price, J. V., \& Steinman, L. (2013a). Science communication to the general public: Why we need to teach undergraduate and graduate students this skill as part of their formal scientific training. Journal of Undergraduate Neuroscience Education, 12 (1), E6-E10. Retrieved from http://www.ncbi.nlm.nih.gov/pmc/articles/PMC3852879/

Espejaa, A. G., \& Lagaróna, D. C. (2015). Socio-scientific issues (SSI) in initial training of primary school teachers: Pre-service teachers' conceptualization of SSI and appreciation of the value of teaching SSI. Procedia - Social and Behavioral Sciences 196, $80-88$.

Evagorou, M., Jimenez-aleixandre, M. P., \& Osborne, J. (2012). "Should We Kill the Grey Squirrels?" A Study Exploring Students'Justifications and Decision-Making. International Journal of Science Education, 34 (3), 401-428.

Field, A. (2000). Discovering Statistics using SPSS for Windows. London - Thousand Oaks New Delhi: Sage publications

Gravetter, F., \& Wallnau, L. (2014). Essentials of statistics for the behavioral sciences (8th ed.). Belmont, CA: Wadsworth.

Griffiths, R. (2004). Knowledge production and the research-teaching nexus: the case of the built environment disciplines. Studies in Higher Education, 29 (6), 709-726.

Healey, M. (2005). Linking research and teaching: exploring disciplinary spaces and the role of inquiry-based learning. In R. Barnett (Ed.), Reshaping the University: New relationships between research, scholarship and teaching (pp. 67-78). London: McGraw Hill and Open University Press.

Healey, M., \& Roberts, J. (eds) (2004). Engaging Students in Active Learning: Case studies in geography, environment and related disciplines. Cheltenham: Geography Discipline Network and School of Environment, University of Gloucestershire.

Igwebuike, T., \& Oriaifo, S. (2012). Effect of a Constructivist Instructional Strategy on Affective Outcomes by Integrated Science Students. International Review of Contemporary Learning Research. 3 (1), 1-10.

Jurik, V., Gröschner, A., \& Seidel, T. (2014). Predicting students' cognitive learning activity and intrinsic learning motivation: How powerful are teacher statements, student profiles, and gender? Learning and Individual Differences 32, 132-139.

Mercer-Mapstone, L., \& Kuchel, L. (2015). Teaching Scientists to Communicate: Evidencebased assessment for undergraduate science education, International Journal of Science Education, 37:10, 1613-1638, DOI: 10.1080/09500693.2015.1045959. 
Minner, D. D., Levy, A. J., \& Century, J. (2010). Inquiry-based science instruction - what is it and does it matter? Results from a research synthesis years 1984 to 2002. Journal of research in science teaching, 47 (4), 474-496.

Okada, A. (2013). Scientific Literacy in the digital age: tools, environments and resources for co-inquiry. European Scientific Journal, 4, 263-274.

Okada, A., Young, G., \& Sanders, J. (2015). Fostering Communities of Practices for teachers' professional development integrating OER and MOOC, EC-TEL. The 10th European Conference on Technology Enhanced Learning.

Osborne, J., Simon, Sh., \& Collins, S. (2003). Attitudes towards science: A review of the literature and its implications, International Journal of Science Education, 25:9, 10491079, DOI: 10.1080/0950069032000032199

Owen, R., Macnaghten, P., \& Stilgoe, J. (2012). Responsible research and innovation: From science in society to science for society, with society. Science \& Public Policy (SPP), 39 (6), 751-760. doi:10.1093/scipol/scs093

Pellegrino, J. W., \& Hilton, M. L. (Eds.). (2013). Education for life and work: Developing transferable knowledge and skills in the 21st century. National Academies Press.

Rietveld, T., \& Van Hout, R. (1993). Statistical Techniques for the Study of Language and Language Behaviour. Berlin - New York: Mouton de Gruyter.

Rocard, M., Csermely, P., Jorde, D., Lenzen, D., Walberg-Henriksson, H., \& Hemmo, V. (2007). Rocard report: "Science education now: A new pedagogy for the future of Europe". EU 22845, European Commission.

Ryan, R. M., \& Deci, E. L. (2002). An overview of self-determination theory: an organismicdialectical perspective. In E. L. Deci \& R. M. Ryan (Eds.), Handbook of selfdetermination research (pp. 3-33). Rochester: The University of Rochester Press.

Ryan, R. M., \& Deci, E. L. (2009). Promoting self-determined school engagement. In K. R. Wentzel \& A. Wigfield (Eds.), Handbook of motivation at school. New York: Taylor \& Francis.

Ryan, R. M. (1982). Control and information in the intrapersonal sphere: An extension of cognitive evaluation theory. Journal of Personality and Social Psychology, 43, 450-461.

Sherborne, T. et. al. (2014). ENGAGE: Equipping the Next Generation for Active Engagement in Science. http://cordis.europa.eu/project/rcn/111469_en.html.

Stefanou, C. R., Perencevich, K. C., DiCintio, M., \& Turner, J. C. (2004). Supporting autonomy in the classroom: Ways teachers encourage student decision making and ownership. Educational Psychologist, 39, 97-110. doi:10.1207/s15326985ep3902 2.

Von Schomberg, R. (2011). Prospects for technology assessment in a framework of responsible research and innovation. In. Dusseldorp, M \& Beecroft, R. (Eds.), Technikfolgen abschätzen lehren. Bildungspotenziale transdisziplinärer Methoden. Wiesbaden: Vs Verlag, pp. 39-61.

Zeidler, D. L., \& Nichols, B. H. (2009). Socioscientific Issues: Theory and Practice. Journal of Elementary Science Education, 21 (2), 49-58. 